\title{
IMÁGENES RELIGIOSAS COMO FUNCIONES SEMIÓTICAS DE LA DEVOCIÓN POPULAR CATÓLICA. LA PEREGRINACIÓN GUADALUPANA DE LOS TRABAJADORES MINEROS EN ZIMAPÁN, HIDALGO
}

\author{
Laura Elena CORONA DE LA PEÑA \\ Dirección de Etnología y Antropología Social del Instituto \\ Nacional de Antropología e Historia (México) \\ laura-elena_corona@hotmail.com

\begin{abstract}
Leonardo VEGA FLORES
Postgrado de Historia, Universidad Nacional Autónoma de México

(México)

famvefl@hotmail.com
\end{abstract}

Resumen: Se analizan imágenes católicas como funciones semióticas de la devoción popular, sobre el caso específico del peregrinar guadalupano de un grupo de trabajadores mineros en el municipio de Zimapán, Hidalgo, México. 
Abstract: We analyze catholic images as semiotic functions of popular devotion, for the specific case of the guadalupan pilgrimage of a group of mine workers in the municipality of Zimapan locate in the state of Hidalgo, Mexico.

Palabras clave: Imágenes católicas. Trabajadores mineros. Peregrinación guadalupana. México.

Key Words: Catholic Images. Mine Workers. Guadalupan pilgrimage. México.

\section{INTRODUCCIÓN}

En este trabajo presentamos algunos de los resultados de la investigación desarrollada para la Dirección de Etnología y Antropología Social en el periodo comprendido entre enero 2002 y diciembre 2005, durante el cual se realizaron distintas temporadas de campo y se aplicaron entrevistas a trabajadores y ex trabajadores mineros, así como a directivos y personas del municipio de Zimapán, en el estado de Hidalgo, en México. Se trata de un proyecto de investigación en el que desde su inicio se ha buscado integrar las herramientas teórico-metodológicas de la etnología con las de la semiótica. En esta ocasión analizaremos una expresión devocional particular, la participación de los trabajadores mineros de la Unidad El Monte en una de las muchas peregrinaciones que en México se dedican a la Virgen de Guadalupe. Para el análisis hemos aplicado los conceptos que Umberto Eco (1975 [1988: 200]) ha utilizado para explicar el signo cognitivo: el type y el token. La peregrinación a la que nos referimos se realiza a pie desde la Ciudad de Zimapán hasta el Santuario de la Virgen de Guadalupe en el pueblo de Francisco I. Madero, más conocido como Guadalupe ${ }^{1}$.

\section{LA DEVOCIÓN GUADALUPANA Y SUS EXPRESIONES}

La Virgen María es el resultado de una función semiótica en la que se correlacionan dos planos: 1) del contenido, según el cual se trata de la madre

\footnotetext{
${ }^{1}$ Cabe aclarar que como empleados de Peñoles, los trabajadores a quienes nos referimos participaron colectivamente en la peregrinación hasta el año 2002, porque la Unidad El Monte cerró en febrero de 2003.
} 
de Jesús; y 2) de la expresión, en el que se le representa a través de distintos soportes materiales. En este sentido la idea de la Virgen María constituye la imagen conceptual o el type $e^{2}$; mientras que sus representaciones son los tokens, entre los cuales se cuentan también sus numerosas advocaciones como lo es la Virgen de Guadalupe, que a su vez adquiere carácter de imagen conceptual o type y, por lo tanto, tiene también varias imágenes representadas que constituyen sus interpretantes o tokens y que son esculturas, estampitas, cuadros, medallas, tatuajes, etc. El culto a la Virgen de Guadalupe, es decir al type, se hace a través de sus imágenes representadas o tokens, a los que por medio de la bendición se ha transferido lo que LeviStrauss (1973: 210) llamó eficacia simbólica y que en este caso es el poder o capacidad sagrada a través de la cual la Virgen protege, escucha y auxilia a sus devotos.

La devoción a la Virgen de Guadalupe es la devoción mariana más extendida en México y se expresa de distintas formas:

\begin{tabular}{|c|c|c|c|c|c|}
\hline \multicolumn{2}{|c|}{$\begin{array}{l}\text { Expresión } \\
\text { devocional }\end{array}$} & Vehículo material & Actor & Tiempo & Espacio \\
\hline \multirow{2}{*}{$\begin{array}{l}\frac{\pi}{0} \\
\text { D્⿹ } \\
0\end{array}$} & Material & $\begin{array}{l}\text { Objetos considerados } \\
\text { valiosos }\end{array}$ & $\begin{array}{l}\text { Persona o } \\
\text { grupo }\end{array}$ & $\begin{array}{l}\text { Constante, efímera, } \\
\text { cíclica o extraordinaria }\end{array}$ & $\begin{array}{l}\text { Público o } \\
\text { privado }\end{array}$ \\
\hline & Acción & $\begin{array}{l}\text { Acciones consideradas } \\
\text { difíciles }\end{array}$ & $\begin{array}{l}\text { Persona o } \\
\text { grupo }\end{array}$ & $\begin{array}{l}\text { Efímera, cíclica o } \\
\text { extraordinaria }\end{array}$ & $\begin{array}{l}\text { Público o } \\
\text { privado }\end{array}$ \\
\hline \multicolumn{2}{|c|}{ Altares } & $\begin{array}{l}\text { Objetos en composiciones } \\
\text { visuales y espaciales }\end{array}$ & $\begin{array}{l}\text { Persona o } \\
\text { grupo }\end{array}$ & Constantes cíclicos & $\begin{array}{l}\text { Público o } \\
\text { privado }\end{array}$ \\
\hline \multicolumn{2}{|c|}{ Oración } & $\begin{array}{l}\text { Ondas sonoras e imágenes } \\
\text { mentales }\end{array}$ & $\begin{array}{l}\text { Persona o } \\
\text { grupo }\end{array}$ & Efímera & $\begin{array}{l}\text { Público o } \\
\text { privado }\end{array}$ \\
\hline \multicolumn{2}{|c|}{ Cantos y alabanzas } & Ondas sonoras & $\begin{array}{l}\text { Persona o } \\
\text { grupo }\end{array}$ & Efímera & $\begin{array}{l}\text { Público o } \\
\text { privado }\end{array}$ \\
\hline
\end{tabular}

Las ofrendas materiales son objetos que se ofrecen a la Virgen de Guadalupe, tales como veladoras, flores, bonanzas y algunas promesas ${ }^{3}$, así

2 Umberto Eco (1975 [1988: 200]), con base en la teoría de Charles Sanders Peirce, define el type como un signo que prevé el empleo, como interpretantes y vehículos suyos, de una serie de otros signos o tokens.

${ }^{3}$ Objetos que se prometen llevar a la Virgen una vez que ésta concede al devoto el favor solicitado. 
como estructuras decorativas ( andas $^{4}$, tapetes $^{5}$, portadas $^{6}$, enflorados ${ }^{7}$ y fuegos pirotécnicos. En cuanto a las ofrendas acción, las hemos definido como el hecho de dedicar a la Virgen de Guadalupe, el hacer o dejar de hacer algo, por lo que incluimos a las fiestas, peregrinaciones, procesiones, plegarias, algunas oraciones, promesas, mandas ${ }^{8}$ y juramentos ${ }^{9}$.

Los altares son estructuras de distintos tamaños ubicados en espacios como el hogar, el trabajo o la calle, en los que se colocan ofrendas objeto (veladoras, flores, bonanzas, etc.), además de imágenes de bulto o cuadros de santos, cristos, vírgenes, etc. En cuanto a las oraciones, estas pueden ser en voz alta o en silencio, individuales o colectivas y decirse en un espacio público o privado, implican la lectura o memorización de un texto o la interpretación libre del mismo por parte de los devotos, además de lo que podría llamarse una comunicación libre en la que la persona se dirige directamente a la virgen, a un cristo o un santo. Por lo que toca a los cantos y alabanzas, se trata de textos memorizados con secciones repetitivas, que se dicen o cantan en voz alta, algunos se acompañan de música y ambos pueden llevarse a cabo en distintos espacios como el templo, el altar o bien durante una procesión o peregrinación.

\section{LA PEREGRINACIÓN A PIE EN ZIMAPÁN}

La peregrinación se realiza en un espacio que actualmente conocemos como municipio de Zimapán que es uno de los 84 municipios del estado de Hidalgo (Mapa n. ${ }^{\circ}$ 1), se caracteriza por un paisaje semidesértico, cuya historia ha sido delineada en gran medida por las bonanzas y borrascas de la minería. La Iglesia Católica fue la primera en difundir su doctrina ${ }^{10}$ en el si-

\footnotetext{
${ }^{4}$ Estructuras generalmente hechas de madera y decoradas con distintos materiales sobre las que se colocan imágenes religiosas para ser trasladadas durante una procesión o peregrinación.

${ }_{5}$ Decorados colocados sobre el piso, hechos con distintos materiales como son el aserrín y las flores. Se ponen en los lugares por donde pasa una procesión o una peregrinación.

${ }^{6}$ Arcos decorados con distintos materiales por donde pasan procesiones o peregrinaciones y que indican cambios de espacio; son una especie de puerta abierta.

7 Arreglos florales colocados en los templos o en los altares con motivo de una celebración específica.

8 Acciones que se compromete a realizar un devoto como agradecimiento a la Virgen por concederle un favor. Por lo general se trata de visitas a santuarios o de maneras de vestir o de cambios corporales (raparse, cortarse el cabello o dejárselo crecer, etc.).

${ }^{9}$ Compromiso que ofrece el devoto a la Virgen, algunos se redactan en tarjetas que se compran en los santuarios, en ellas la persona anota su nombre para después llevarla consigo todo el tiempo. Por lo general se trata de promesas como dejar de beber, ser fiel, etc.

${ }^{10}$ A través de los franciscanos, cuya labor fue continuada por agustinos, dominicos y finalmente por el clero secular, a partir de 1729.
} 
glo XVIII y sigue siendo la de mayor número de adeptos; posteriormente, en el transcurso del siglo XIX se asentaron Iglesias Evangélicas Históricas ${ }^{11}$ y, a partir del siglo XX, han llegado Iglesias Pentecostales ${ }^{12}$ e Iglesias Bíblicas no Evangélicas $^{13}$, así como otras denominaciones cristianas ${ }^{14}$.

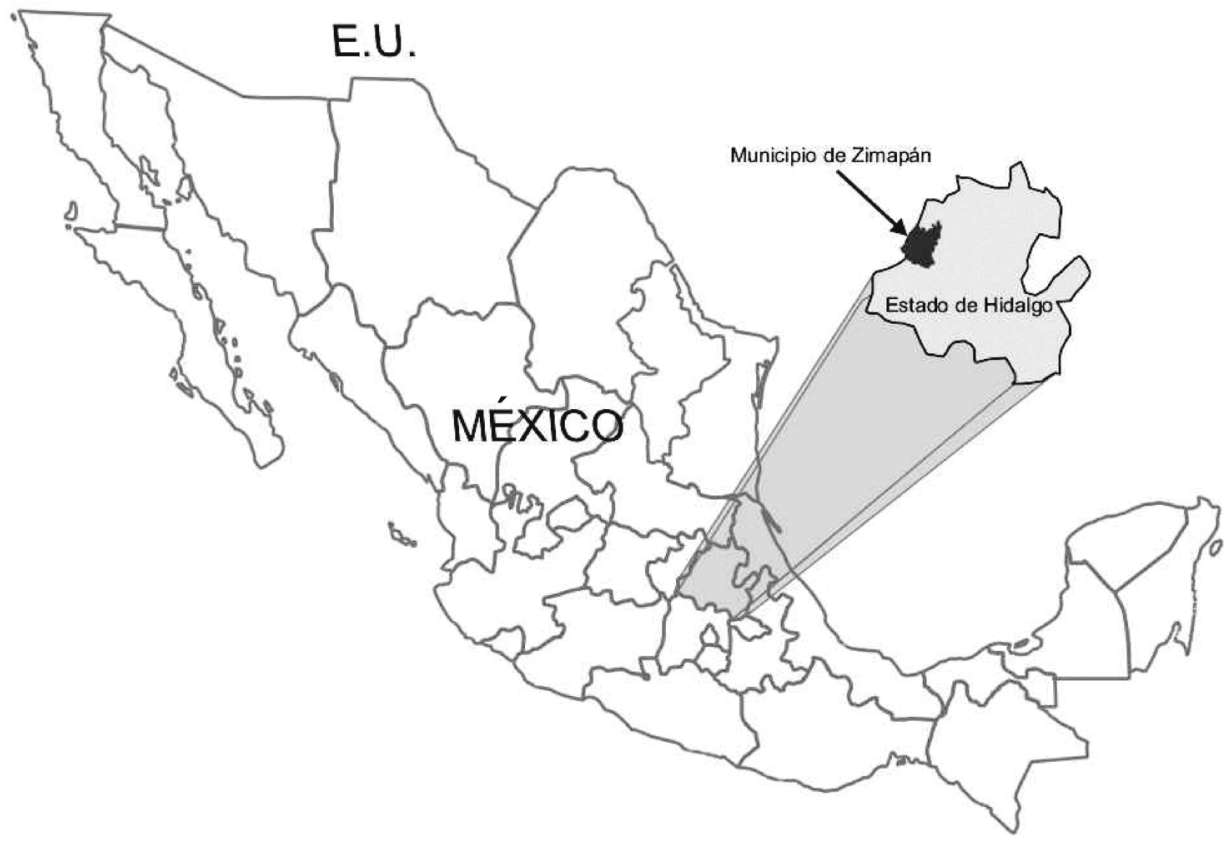

Mapa n. 1: El municipio de Zimapán, Hidalgo.

Desde principios del siglo Xx, cada 12 de diciembre se ha llevado a cabo esta peregrinación, organizada por un comité encabezado por el párroco y en ella participan entre 16 y 20 grupos laborales incluidos trabajadores emigrantes a Estados Unidos; cada uno de ellos asiste con la imagen de la Virgen que normalmente está en sus lugares de trabajo, a la que llevan sobre las llamadas ofrendas (Esquema n. ${ }^{\circ}$ 1, Fotografía n. ${ }^{\circ}$ 1), que son estructuras de madera, adornadas con flores de distintos materiales. Para la elaboración de es-

\footnotetext{
11 Siguen presentes la Bautista, la Presbiteriana, la Evangélica y la Metodista.

12 Dios Vivo, Columna y Apoyo de la Verdad (La Luz del Mundo), las Iglesias del Evangelio Cuadrangular en México Asociación Religiosa (A. R.) o la Iglesia Cristiana Independiente Pentecostés (A. R.)

13 Iglesia de Dios del Séptimo Día (A. R.), los Testigos de Jehová y los Adventistas.

14 Iglesia Cristiana Visión Misión y Crecimiento y las Misiones Transmundiales.
} 
tas estructuras se sigue un código o acuerdo en el que se indica tamaño, forma y elementos visuales. El tamaño promedio es de 2 metros de largo por 1,5 metros de ancho y 1,7 metros de altura con el arco floral, al frente del cual se colocan las imágenes, los tokens, rodeadas de adornos con motivos florales. El costo depende de los materiales, aunque generalmente se reutilizan muchos elementos; las flores pueden ser naturales, de plástico, de papel o de cera, las más caras son las naturales porque es una región árida.

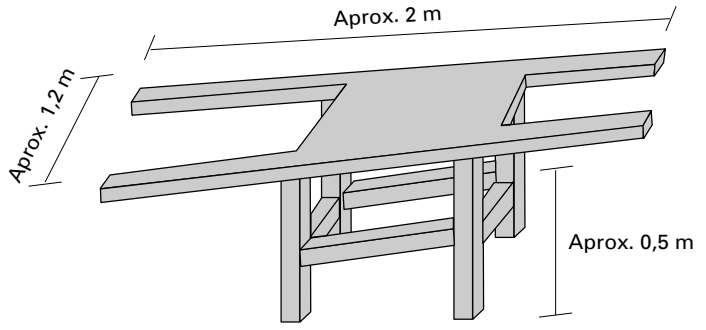

Fuente: Trabajo de campo.

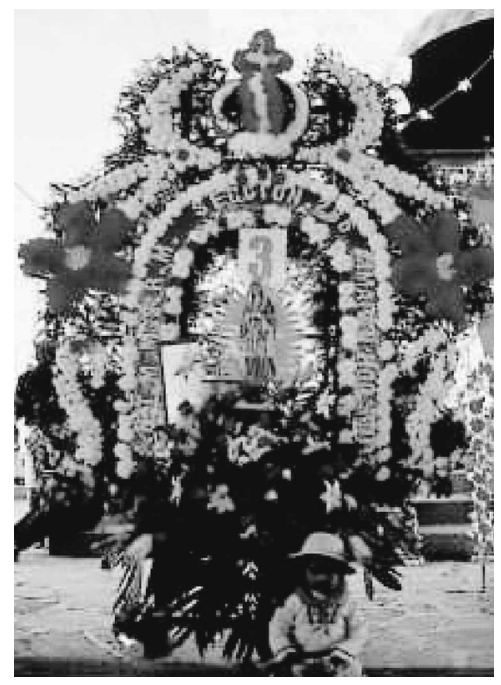

Fotógrafo: Leonardo Vega Flores, septiembre 2004 .

Fotografía n. ${ }^{\circ}$ 1: Ofrenda.

Esquema n. ${ }^{\circ}$ 1: Estructura de la ofrenda.

El día 11 de diciembre, la víspera, casi todos los grupos llevan sus ofrendas a la parroquia de San Juan Bautista en un ambiente festivo; ese día llegan algunos grupos como la Antorcha Guadalupana o la Peregrinación Ciclista, desde la Basílica de Guadalupe en la Ciudad de México, que a su vez acudirán al santuario en el pueblo de Guadalupe el día 12. También están presentes muchos emigrantes que llegan desde distintos lugares para pasar sus vacaciones y asistir a alguna de las peregrinaciones.

El día 12, al amanecer, se ofrece a las imágenes una serenata con mariachis, pero es hasta las 8 de la mañana cuando empiezan a llegar los peregrinos e inician los últimos preparativos. Cuando se acerca el momento de salir, 
las ofrendas se forman en dos filas, afuera del atrio, y en ellas las imágenes esperan la bendición del sacerdote, quien camina entre las ofrendas, saludando a los presentes y dando indicaciones; después de algunos rezos y cantos el párroco bendice las ofrendas y da la salida; todos inician la peregrinación a paso rápido entre el estruendo de cohetes y el tañer de las campanas. Al frente van los coheteros, marcando el paso, seguidos de voluntarios que dan indicaciones a peregrinos y vehículos, siguen las ofrendas y después otros participantes. La peregrinación recorre los 9 kilómetros entre Zimapán y Guadalupe (Mapa n. ${ }^{\circ}$ 2) en aproximadamente 3 horas; las personas caminan bajo un sol que brilla con gran intensidad y en el camino algunos vecinos les ofrecen agua $o$ fruta.

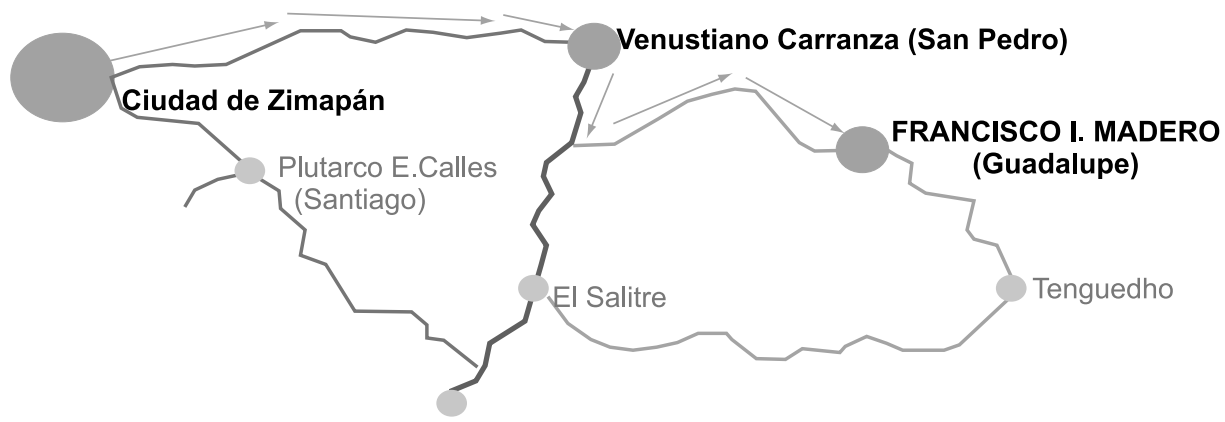

Fuentes: INEGI 2003: s/p, INEGI (1995: 3). Trabajo de campo.

Mapa n. ${ }^{\circ}$ 2: Recorrido de la peregrinación.

Cuando llegan al santuario, los peregrinos colocan sus ofrendas en el atrio, a un lado del templete, donde el sacerdote oficiará la misa. Una gran lona protege a todos los asistentes del sol; la ceremonia acompañada de coros sigue el orden de una celebración dominical y dura más de una hora; al decir las peticiones, el padre agradece la presencia de los distintos grupos, nombrándolos a cada uno, después de lo cual los asistentes aplauden. Al terminar la misa, las imágenes se quedan en la ofrenda y muchas personas y familias se retratan frente a ellas hasta el atardecer. Algunos visitan la capilla donde reciben una limpia y todos disfrutan de la feria con sus familiares y amigos. 


\section{DEVOCIÓN GUADALUPANA DE LOS TRABAJADORES MINEROS}

Muchos de los trabajadores mineros de la Unidad El Monte veneran a la Virgen de Guadalupe en los altares de la mina Lomo de Toro, donde hay una imagen de bulto y en la planta concentradora ${ }^{15}$, donde hay una imagen bidimensional. Frente a los altares de su lugar de trabajo, los devotos de la Virgen se le encomiendan antes de iniciar su jornada, al salir se persignan frente al altar y de vez en vez le llevan como ofrenda una veladora o una bonanza ${ }^{16}$ (Fotografía n. ${ }^{\circ}$ 2). Las imágenes en los altares son tokens de la Virgen de Guadalupe, es decir, del type, cuya eficacia simbólica se refrenda año, con año a través de la peregrinación y por medio de la bendición, el canto, los rezos, las ofrendas, etc.; a través de todos estos procedimientos las imágenes adquieren, además, social y públicamente su carácter de imágenes provistas del poder protector del type.

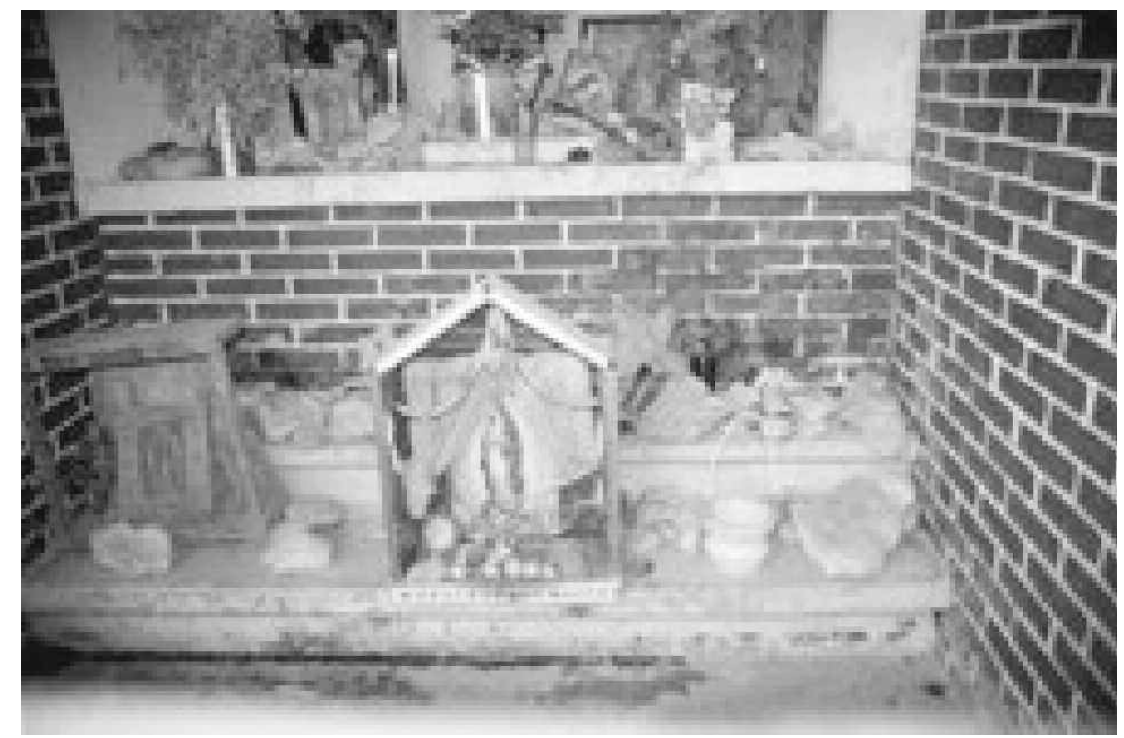

Fotógrafo: Leonardo Vega Flores, septiembre 2004.

Fotografía n. ${ }^{\circ}$ 2: Bonanzas en un altar.

\footnotetext{
${ }^{15}$ Lugar donde se muele el mineral extraído de la mina para obtener los metales que contiene.

16 Veta muy rica en una mina. Los trabajadores mineros de la Unidad El Monte llamaban así a un trozo de mineral que consideran bonito.
} 
Para los trabajadores mineros, devotos de la Virgen, es muy importante participar en la peregrinación y para ello uno de sus representantes sindicales asiste a las reuniones preparatorias en la parroquia y hace los arreglos necesarios en la empresa para gestionar apoyos como playeras o sudaderas, pago de la ofrenda y asistencia de la ambulancia de la compañía para acompañar la peregrinación. Las imágenes de los trabajadores mineros inician su peregrinar con días de anticipación. Primero pasan por la oficina sindical, donde reciben una cuidadosa limpieza y de allí son trasladadas a la florería contratada para elaborar la ofrenda. Durante la peregrinación, los trabajadores mineros se turnan para cargar la ofrenda y bajo el intenso sol, sudan ligeramente, pero ninguno se quita su sudadera y cuidan en todo momento el estado de las imágenes. El grupo, como los demás, se mantiene compacto y no hay mucha plática.

Una vez en el santuario, los trabajadores mineros colocan su ofrenda en el lugar asignado en el atrio y se mantienen de pie frente a ella para escuchar con devoción la misa. Las imágenes miran hacia los devotos y durante la celebración se les trata como participantes importantes de la misma. Así, el momento de dar la paz, los trabajadores mineros, en primer lugar, se inclinan ante sus imágenes; después se dan la paz entre ellos y luego a los demás asistentes. Los trabajadores mineros terminan su peregrinar visitando a la imagen del santuario en la ermita, lugar en el que se hacen limpias y se recibe la reliquia $^{17}$ al dejar la limosna. Después del peregrinar, viene la fiesta y es momento de disfrutar de la feria con sus puestos de ropa, trastes, barbacoa, carnitas, quesadillas, sopes, etc.; o bien de sentarse en el pasto para compartir con la familia los alimentos que se hayan llevado. Finalmente, la mayoría se retira antes de que caiga la noche y esperan a que pase otro año para volver a peregrinar con sus imágenes y visitar a la Virgen del santuario en el Pueblo de Francisco I. Madero; mientras que los trabajadores designados van por las imágenes, las separan de la ofrenda y las transportan a la oficina sindical de donde volverán a sus altares y continuarán protegiendo a sus devotos.

\section{EL SENTIDO DE LA PEREGRINACIÓN}

Como puede verse, en este caso de devoción popular católica, la imagen conceptual tiene varias imágenes representadas, a las que se dirigen los de-

${ }_{17}$ Es una ramita de romero con una flor y, a veces, una estampita que son el recordatorio de la peregrinación que se realizó. 
votos y cada grupo de peregrinos reconoce la eficacia de su propia Virgen. La función semiótica depende de las reproducciones y el tipo expresivo concuerda con el tipo de contenido como lo prevé el código. Las imágenes, por lo tanto, cumplen con las características físicas y devocionales, tanto de la Virgen María como de la Virgen de Guadalupe, en el plano del contenido y en el de la expresión en sus múltiples niveles.

Considerando lo planteado anteriormente, la devoción es una forma de expresar los sentimientos del creyente hacia la Virgen de Guadalupe y puede materializarse de varias maneras. En el caso específico de las peregrinaciones, las personas ofrecen su recorrido hasta el santuario y esto implica un esfuerzo físico al caminar bajo el sol, el valor del esfuerzo ofrecido se incrementa al llevar cargando objetos pesados como las andas o arreglos florales. El sentido y motivo de esta peregrinación es agradar a la Virgen de Guadalupe, es decir, al type, representado en las distintas imágenes o tokens y de esta manera los devotos le expresan su agradecimiento y cariño, además de cumplir y refrendar su compromiso de celebrarla anualmente, con lo que, entre otras cosas, aseguran su protección durante otro año.

La idea de protección es particularmente importante entre los trabajadores mineros, ya que su labor transcurre en condiciones difíciles y peligrosas que incluyen aspectos como la profundidad ${ }^{18}$, temperatura ${ }^{19}$, iluminación escasa, necesidad de fuerza física y resistencia, etc., y que, a su vez, determinan ciertos riesgos de enfermedad y accidente. En cuanto al riesgo, es importante mencionar que éste varía de una a otra compañía, independientemente de la existencia de normas oficiales mexicanas que regulan este tipo de actividad; esto se debe, por un lado, al tipo de mina y material que se explota y, por otro, al equipo de protección y capacitación que reciben los trabajadores. En cuanto a la práctica religiosa de estos trabajadores, es oportuno mencionar lo siguiente:

1. La religión más común entre los trabajadores mineros de la Unidad El Monte y en general de la empresa Fresnillo, es la católica ${ }^{20}$, aunque hay trabajadores mineros y empleados que se adscriben a alguna iglesia protestante y es notorio el aumento paulatino de los no católicos. Uno de los directivos describe la religión de los trabajadores así:

\footnotetext{
${ }^{18}$ En el área de mina de la Unidad El Monte se trabaja a distintas profundidades, que pueden ser de hasta 450 metros.

19 Se incrementa al aumentar la profundidad.

${ }^{20}$ Entre los trabajadores mineros entrevistados para este trabajo, el $81.8 \%$ afirmaron ser católicos, el 9\% dijo no tener religión y otro 9\% expresó haber sido católico y estar decepcionado de la religión.
} 
...tradicionalmente, y en toda la República, el trabajador minero es una persona que respeta mucho sus tradiciones, podemos decir que casi el 100\% son católicos. Les gusta festejar o celebrar las festividades religiosas, la más fuerte o la más importante es la del 12 de diciembre, la de la Virgen de Guadalupe [...] son un grupo de trabajadores, vamos a llamarlos 'rudos', pero sencillos a la vez...

...la religión no es un tema que se trate entre los mineros; en el peor de los casos los católicos se burlan de los que son "hermanos"2l y dicen "éste no pistea $»^{22}$, pero otras cosas más delicadas no, no podemos decir que haya conflictos o discrepancias o discusiones o agresiones por las cuestiones religiosas, al menos no en esta zona.

2. Algunos trabajadores mineros continúan siendo católicos, aunque sus familias se hayan convertido a otra religión. Otros han dejado de ser católicos y critican el consumo de alcohol entre los compañeros que aún lo son. Así se expresó un trabajador:

...como le digo, yo no tomaba y me disgustaba estar ahí alegando con los que sí tomaban. En mi casa en San Andrés peleaban delante de los santos y mejor decidí quitarlos. Los compañeros católicos dicen que son muy religiosos, pero maldicen, golpean, etc., así que de nada sirve lo católico.

3. Entre los trabajadores católicos varían las expresiones de religiosidad realizadas en el trabajo. En los altares predominan las imágenes de la Virgen de Guadalupe, en la Unidad El Monte hay uno en la rampa de entrada a la mina y otro en la planta de beneficio. Las imágenes fueron llevadas por los trabajadores, quienes, después, solicitaron a la empresa la construcción de un altar para colocarlas y son los trabajadores quienes se encargan del cuidado del altar y de las imágenes. Algunos se persignan al pasar por el altar, otros se detienen a orar, algunos se hincan, etc. De los trabajadores mineros entrevistados la mayor parte dijo que «hacía sus peticiones mentalmente».

4. En sus casas, a la mayoría de los trabajadores católicos entrevistados, sus esposas «los despiden persignándolos y prendiendo una veladora blanca» $\mathrm{y}$ varios comentaron que tienen un altar familiar.

\footnotetext{
21 Se refiere a que son protestantes y los católicos los llaman hermanos.

${ }^{22}$ Quiere decir que no toma alcohol. El consumo de alcohol es muy alto entre los trabajadores mineros; es una forma de socialización y se considera una de sus características, porque se dice que son muy hombres.
} 
5. La devoción católica más extendida entre los trabajadores mineros de la unidad y de la compañía es la dedicada a la Virgen de Guadalupe. De ahí, que, en el contrato colectivo, el día 12 de diciembre se mencione como un «día festivo oficial» y se otorgue un permiso colectivo sin goce de sueldo.

6. Para los trabajadores mineros guadalupanos es muy importante la celebración del 12 de diciembre y, cuando hubo mejores condiciones económicas, traían a un sacerdote para que oficiara misa en la bocamina; sin embargo, ahora, la celebración se enfoca a la peregrinación a Guadalupe. Por lo general, los trabajadores mineros no acostumbran acudir a otros santuarios y consideran que su vida no gira en torno a las festividades o a la religión. Ninguno de los trabajadores católicos entrevistados ha participado con algún cargo (mayordomo, fiscal, encargado, etc.) en la organización de ninguna fiesta religiosa. Pero todos manifestaron asistir a la peregrinación del día 12 de diciembre y comentaron que es la única festividad religiosa en la que participan como grupo. De ahí que se haya conseguido que su sindicato los apoye con el pago del arreglo floral y que la compañía preste una ambulancia para cubrir el trayecto.

7. Ya no son muy comunes las creencias mágico-religiosas, relativas a la mina, por lo que pocos trabajadores están en contra de que entren mujeres en función de que «la mina es una mujer y se encela».

Entre los aspectos de la práctica religiosa, que hemos mencionado, destaca como una de las expresiones de devoción más relevantes para los trabajadores mineros su peregrinar guadalupano, cuya importancia radica, de acuerdo con nuestro análisis, en dos aspectos: por un lado, con ella se refrenda el compromiso entre los devotos y el type; y por otro lado, el token reafirma su eficacia simbólica a través del peregrinar y de esta manera puede continuar su labor protectora y benéfica. Como parte del análisis, otro aspecto que vale la pena subrayar es el empleo de signos particulares durante la peregrinación, con los cuales los trabajadores mineros comunican mensajes sobre sí mismos y, por lo tanto, nos parece pertinente describirlos:

1. Los de lectura directa: en las playeras o sudaderas (Fotografía n.$^{\circ} 3$ ) y listones impresos (Imagen n. ${ }^{\circ} 1$ ), que portan durante la peregrinación, lo mismo que en su ofrenda (Fotografía n. ${ }^{\circ} 4$ ), distinguimos 4 elementos o signos: a) su sección sindical ${ }^{23}$, que los identifica como trabajadores mineros, tanto a través de su logotipo (Imagen ${ }^{\circ}{ }^{\circ}$ 2), como del propio texto Sección

${ }^{23} 286$ del Sindicato Nacional de Trabajadores Mineros, Metalúrgicos y Similares de la República Mexicana (SNTMMySRM). 
286; b) la palabra Zimapán que los incluye como parte del municipio; c) la imagen de la Virgen de Guadalupe con la que manifiestan su devoción católica; y d) el año de la peregrinación. Todos estos signos han sido elegidos por los trabajadores mineros para plasmarse en los objetos a que hacemos referencia y los mensajes que estos signos transmiten a los demás son muy explícitos.

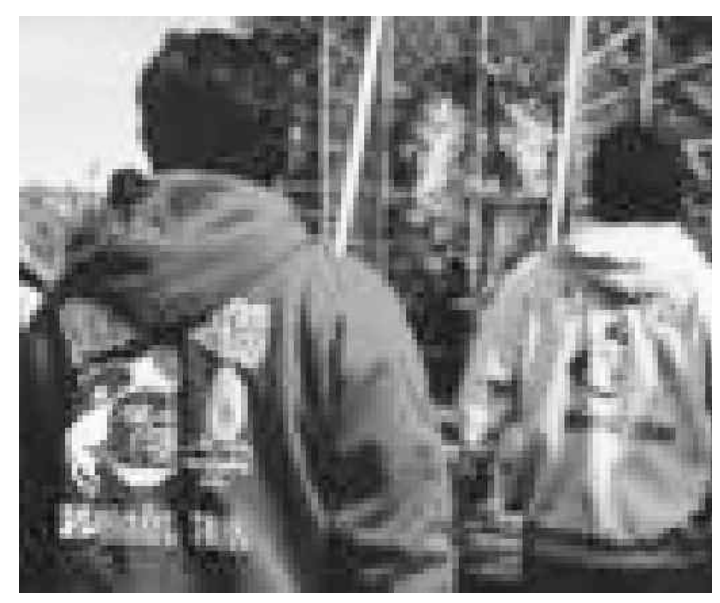

Fotógrafo: Leonardo Vega Flores, diciembre 2002.

Fotografía n. ${ }^{\circ}$ 3: Sudaderas 2002.

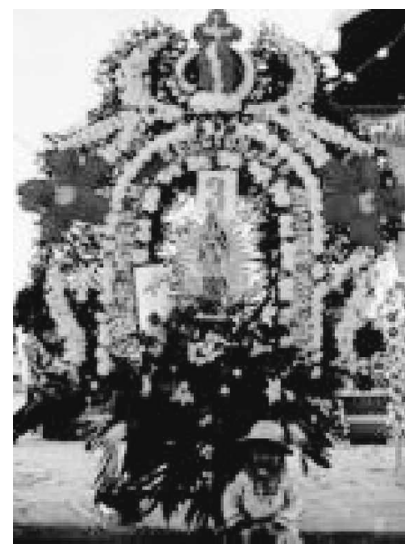

Fotógrafo: Leonardo Vega Flores, diciembre 2002.

Fotografía n. ${ }^{\circ}$ : Ofrenda 2002.

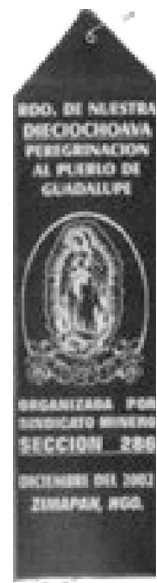

Fuente:digtalización directa

Imagen n. ${ }^{\circ}$ 1: Listón impreso.

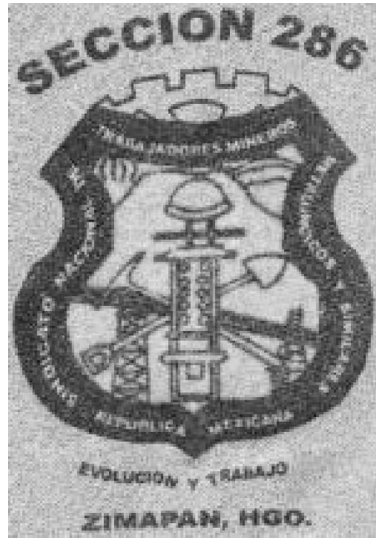

Fuente: digitalización directa.

Imagen $n .^{\circ} 2$ : Logotipo. 
2. Los que requieren un mayor conocimiento sobre los trabajadores mineros y su cultura: en las sudaderas y listones los colores como signos tienen varios contenidos. En este sentido coincidimos con Squicciarino (1986 [2003: 38, 39, 40, 110]), quien considera que «los distintos componentes del aspecto externo [...] adquieren importancia sobre todo por su significado social, es decir, por los mensajes más o menos manipulados, más o menos conscientes», éstos transmiten informaciones en relación con distintos aspectos de quien los porta: edad, sexo, grupo étnico, profesión, etc. Sobre los colores, Squicciarino (1986 [2003: 96-98]) menciona que el color ha manifestado y manifiesta diferencias sociales en torno al sexo, la religión y la actividad laboral, aunque la codificación de los significados no es unívoca y está siempre relacionada con la cultura de que se trate, ya que en el proceso comunicativo se apela necesariamente a referencias culturales que, además, cambian con el tiempo. En el caso de los trabajadores mineros, el color que predomina es el azul, que en la cultura regional se encuentra dentro de un rango que popularmente se considera masculino ${ }^{24}$; pero que, además, es un color que se asocia en el ámbito religioso a lo mariano ${ }^{25}$. Esta confluencia de significados se puede resumir de la siguiente manera:

\begin{tabular}{|l|l|}
\hline Plano de expresión & Plano de contenido \\
\hline \multirow{3}{*}{ Color azul } & Masculinidad \\
\cline { 2 - 2 } & Marianidad (devoción mariana) \\
\cline { 2 - 2 } & Uniforme del trabajador \\
\hline
\end{tabular}

Si bien en esta confluencia aparece una aparente contradicción: masculino vs. mariano, ésta se explica porque el llevar el color de la Virgen no indica algo femenino, sino el cariño por la madre, que es una imagen recurrente asociada a la devoción por la Virgen María por la Virgen de Guadalupe.

\section{REFLEXIONES FINALES}

Contemplar las imágenes católicas como funciones semióticas permite reconocer planos del contenido y de la expresión, y de esta forma distinguir

24 Este color también es el utilizado en los uniformes que utilizan para su trabajo.

25 Relativo a la Virgen María. 
procesos comunicativos presentes en la práctica religiosa, además de particularidades devocionales de distintos grupos como son los trabajadores mineros a quienes nos referimos en esta investigación. En el caso que analizamos, tal como lo expusimos, están presentes elementos de diversos sistemas comunicativos - además del religioso - como son los aspectos laborales y la propia imagen del trabajador minero; todos ellos se expresan a través de uno o varios aspectos en su vestir, actuar y pensar.

A partir de nuestro análisis, consideramos que las peregrinaciones pueden estudiarse como procesos comunicativos, en los que los s-códigos, en términos de Eco (1975 [1988: 153]), se han desarrollado y actualizado durante la historia de cada peregrinación; en el caso abordado se trata de s-códigos de distintos tipos: color, forma, espacialidad, movimiento, gestualidad, etc. Aunque en las peregrinaciones existen aspectos compartidos que pueden considerarse como generales, la lectura de los mensajes en cada caso depende de los s-códigos particulares y de la competencia del lector, por lo que en ella se distinguen niveles que van de lo superficial y claramente explícito hasta lo profundo y lleno de contenidos especializados, que, por lo tanto, requieren un conocimiento más amplio de los sistemas culturales involucrados.

\section{REFERENCIAS BIBLIOGRÁFICAS}

B.F.L. (1927). «Superstitions of the Miners of Mexico». Mexican Magazine 1.3 , 10, 546-556. México: Biblioteca del Museo Nacional.

Cid JuRAdo, A. (1999). El glifo mesoamericano como un problema de interpretación y traducción cultural: el caso nahua-mexica. Tesis de doctorado en Semiótica. Bologna: Università degli Studi di Bologna.

- (2004). ¿De qué se ocupa la semiótica? México: ITESM.

Corona DE LA PeÑA, L. (2005). Plegarias desde el socavón. Identidad laboral minera expresada en la devoción católica. El caso de los mineros de la Unidad El Monte de la Compañía de Peñoles en el municipio de Zimapán, Hidalgo. Tesis de licenciatura en Etnología. México: ENAH.

Corona de la PeÑa, L. y Vega Flores, L. (2004). «Imagen conceptual e imágenes representadas: la peregrinación guadalupana de los trabajadores mineros en Zimapán, Hgo.». Ponencia presentada en el Congreso El patrimonio cultural de la imagen. La imagen del patrimonio cultural. México: DEAS/INAH. 
Cubillo Moreno, G. (1991). Los dominios de la plata: el precio del auge, el peso del poder. Empresarios y trabajadores en las minas de Pachuca y Zimapán, 1552-1620. México: INAH (Colección Divulgación).

ECO, U. (1987). Lector in fabula. La cooperación interpretativa en el texto narrativo. Barcelona: Lumen.

- (1988). Tratado de semiótica general. Barcelona: Lumen.

INEGI (1995). Zimapán de Reyes Estado de Hidalgo. Cuaderno estadístico municipal. México: INEGI.

Langenscheidt, A. (1988). Historia mínima de la minería en la Sierra Gorda. México: Rolston-Bain.

LeVI-STRAuss, C. (1973). Antropología estructural. Buenos Aires: Eudeba.

SquicCiARINO, N. (2003). El vestido habla. Madrid: Cátedra. 